\title{
COMPARISON BETWEEN PREGNANT WOMEN' PREFERENCES AND MIDWIVES' PERFORMANCE IN PRENATAL CONGENITAL ANOMALY SCREENINGS COUNSELING IN INDONESIA
}

\author{
Ni Luh Putu Januraheni ${ }^{1}$, Meei-Ling Gau ${ }^{2}$, \\ ${ }^{1}$ Master's Student of National Taipei University of Nursing and Health Sciences, Taipei, Taiwan ${ }^{1}$ \\ ${ }^{1}$ Lecture's of Sekolah Tinggi Ilmu Kesehatan Bali, Bali, Indonesia \\ ${ }^{2}$ Professor of National Taipei University of Nursing and Health Sciences, Taipei, Taiwan
}

\author{
Informasi Artikel: \\ Diterima: Juni, 2017 \\ Disetujui: September, 2017 \\ * Korespondensi penulis. \\ januraheni1992@gmail.com \\ meeiling@ntunhs.edu.tw
}

\begin{abstract}
Abnormalities are the fourth cause of infant and neonatal mortality in Indonesia. In this situation, midwives need to give clear information about anomaly prenatal tests. This studi aims to compare of pregnant women' preferences and midwives' performance about prenatal congenital anomaly screening counseling in Indonesia. The study was carried out at two health centres and two hospitals in Bali from July to September 2016, with 40 midwives and 200 pregnant women. The QUOTE prenatal questionnaire and a cross-sectional descriptive correlative design was used in this study. The result shows that education was the only one of pregnant women demographic data that significant to counseling anomaly screening. The performance of midwives was concluded to perform well on counseling, however as pregnant women perspective, the midwives performance was not as higher as midwives perspective on counseling. The midwives' performance and pregnant women' preferences were influenced by individual's midwife factors on pregnant women-midwives relationship and decision making. Different result was found that health education was more influenced by different person of midwives. There was a different between pregnant women' preferences and midwives' performance about prenatal congenital anomaly screening counseling. The women-midwives relationship and decision making, the variance of midwife's individual different (within variance) was much higher than different midwives (between variance). In terms of health education subscale, the variance of different midwives performance of congenital anomaly screening counseling (between variance) was much higher than individual midwives (within variance).
\end{abstract}

Keywords: Pregnant women, Midwives, Prenatal Counseling

\section{INTRODUCTION}

Success in pregnancy is determined from the antenatal stage. Each antenatal examination consists of information and skills are doing by midwives to pregnant women. In many countries, prenatal screening tests are offered to pregnant women as part of the routine prenatal care and these tests give an estimation of the chance that the child has a particular abnormality. Over the last decades, prenatal testing for congenital anomalies has developed substantially (Korenromp, 2006). Several studies have attempted to stratify the risk of a chromosome abnormality based on the specific fetal anomalies identified (Shaffer et al., 2012). Midwives can play a very important role in educating pregnant women about anomalous scan (Basama, Leonard, \& Leighton, 2004). Abnormalities are the fourth cause of infant and neonatal mortality in Indonesia. The most abnormalities in Indonesia are Trisomy 21 (Down syndrome). Based on Centre for Biodiversity and Biotechnology (ICBB) Bogor, in Indonesia there are more than 300,000 children with Down syndrome while the incidence of people with Down syndrome worldwide is expected to reach 8 million people (Aryanto, 2008).

Currently, Indonesia was doing genetic counseling during screenings as prevention for pregnant women based on midwives and health practitioners laws, counseling as the priority key of health services (Indonesia of Health Minister, 2010b). However, communicated to clients has increased and seems difficult to manage for both counselors and clients (Shiloh, Gerad, \& Goldman, 2006). Many process and outcome studies have been carried out to assess the quality of prenatal counseling as an awareness of 
client preferences is a prerequisite for tailored communication (Martin et al., 2013). Therefore, in this situation, midwives need to give clear information about anomaly prenatal screenings through counseling process to the pregnant women. In the context of antenatal counseling, these counseling functions are referred to as relationship building, health education and decision-making support (Martin et al., 2013)

\section{METHOD}

A cross-sectional descriptive correlative design was choose to describe the demographics, pregnant women' preference and midwives' performance. A convenient sampling was selected to collect the pregnant women and midwives respondent. This study was conducted in two hospitals and two health centers in Bali, Indonesia. The participants in this study are pregnant woman who were above 18 years old, currently in their first or second semester of pregnancy, the pregnant women should be able to read in Bahasa and they agree to participate by signed the inform consent. All midwives in this study were able to read Bahasa and sign the inform consent as a respondent.

The instruments used in this study are demographic information for pregnant women, demographic information for midwives. Data were collected on demographic characteristic of the subjects to gain information on contextual stimuli including midwives demographic factors such as age, religion, work experiences, education, counseling training and pregnant women`s demographic factors such as age, parity, marriage status, family history, religion, education and gestational week. There were two questionnaires of QUOTE prenatal questionnaire in this study. Those were midwives-version questionnaire and pregnant women' version questionnaire that developed and revised by Linda Martin in 2013. The questionnaire used to measure midwives' performance on prenatal congenital anomaly screenings counseling. Included of three components of the QUOTE prenatal questionnaire: 15 items covered the client-midwife relation, 24 items covered health education and 16 items concerned decision-making support. The questionnaire was translated into Bahasa-Indonesia by two bilingual speakers following the forward and backward procedures (Sousa \& Rojjanasrirat, 2010).

The researcher did pilot study for 10 pregnant women and 5 midwives which resulted of Cronbach's alpha. Cronbach's alpha for midwives version were .89 (pregnant women -midwives relationship), .88 (health education), and .89 (decision making). Cronbach's alpha for pregnant women version were .86 (pregnant women midwives relationship), .88 (health education), and .89 (decision making). The items of the questionnaire were formulated as importance statements ('as a midwife I perceive as important for prenatal counseling, that...') to be answered on a 4point Likert scale (Response options were 1, 'not important'; 2,'fairly important'; 3, 'important'; and 4 , 'very important'). The data was analyzed using the Statistical Package for Social Sciences (SPSS) version 18. Descriptive statistics was used to describe the mean, standard deviation, and frequency of the respondent in the study. Multilevel linear modeling was used to compare of pregnant women' preferences and midwives' performance about prenatal congenital anomaly screening counseling in Indonesia.

\section{RESULTS}

\section{Demographic data}

A total of 200 pregnant women completed the study. Mean of the age was $25.26 \pm 5.25$ years old. The highest education level of pregnant women was $45.5 \%$ of senior high school, $25 \%$ were junior high school and only few (3\%) of pregnant women with no education. All of pregnant women $(100 \%)$ were married as respondent. More than half (63.5\%) pregnant women were Hindu. The other pregnant women`s religion were Islam, Christian and Catholic, $27 \%, 5 \%$ and $4.5 \%$ respectively. For midwives, a total of 40 midwives finished the study. The mean of midwife`s age was $31.20 \pm 7.54$ years old. The most of midwives education were diploma III $(97.5 \%)$ and only $2.5 \%$ were diploma IV/Bachelor. All of the midwives were Hindu $(100 \%)$. The average of midwife`s work experiences were $9.33 \pm 6.13$ years. More than about $85 \%$ of midwives had counselling training before they joined the study and relatively few $(15 \%)$ midwives who were not took the counselling training.

\section{Frequencies of Midwives Performance and Pregnant Women Preferences on Congruence during Counselling Anomaly Screening Counselling}

The results show that more than $90 \%$ of the midwives who attached performance well (score 3 or 4) of pregnant women-midwives relationship and decision making during counselling and few $(5 \%)$ of midwives who did insufficiently performance (score 1 or 2) on 15 items of questions. Moreover, $92.5 \%$ 
of the midwives performed well on health education and $7.5 \%$ of the midwives who did insufficiently performance. The results also shows that $88.5 \%$ of pregnant women rated performance well for midwives on 15 items of pregnant women-midwives relationship, the insufficiently performance was perceived by $11.5 \%$. There was only small gap $(0.5 \%)$ between pregnant women-midwives relationship and health education rated which $88 \%$ of performed well on health education and $12 \%$ of insufficiently performed. The third subscale was decision making, the most of pregnant women perceived that the midwives performed well $(76.5 \%)$ and more than one fifth $(23.5 \%)$ rated that midwives insufficiently performed on 16 items of decision making during counselling.

\section{Descriptive Analysis of Each Items Ranked Based on QOUTE Prenatal Questionnaire}

The top three biggest mean of midwives performance on pregnant women-midwives relationship showed that "use clear and comprehensible language" ( $\bar{x}=3.75, S D=0.43)$ was the most important items counselled the pregnant women, the next item was "put my clients at ease" ( $\bar{x}=3.68, S D=0.57)$ also the one items that made midwife performance well. Almost of the midwives showed that "take clients concern seriously" ( $\bar{x}$ $=3.67, \quad S D=0.52$ ) influenced the counselling performance. There were finding of three biggest items on pregnant women-midwives relationship for pregnant women preferences, "take plenty of time to answer my questions" ( $\bar{x}=3.49, S D=0.62)$ was the most that pregnant women thought about midwives performance during counselled. The second reason that midwives used clear and comprehensible language ( $\bar{x}=3.48, S D=0.62$ ) to pregnant women to explained during counselling process. "Open and honest about every aspect of pregnancy" and "gives me enough time to explain myself properly" ( $\bar{x}$ $=3.41, S D=0.62$ ) were the other reasons of pregnant women thought that midwives was performed well.

The other subscale was health education. There were 24 items of health education scale, therefore ranked between 1-24 for midwives performed and pregnant women preferences. Professional $(\bar{x}=3.82$, $S D=0.38$ ) was a highest item that midwives did during counselling. The next was all of midwives concerned that "discusses all pregnant women options with regard to prenatal screening and the implications" ( $\bar{x}=3.75, S D=0.43)$ was an important part to give the best quality of counseling program to pregnant women. "Asks about pregnant women family's history of birth defects" $(\bar{x}=3.75$, $S D=0.49)$ as the highest three of midwives performance items. The highest of pregnant women preferences on health education was professional ( $\bar{x}$ $=3.54, S D=0.58)$ as same as midwives performed item. The same mean was found for the second and third item as rank number two, "discusses all my options with regard to prenatal screening and the implications" ( $\bar{x}=3.53, S D=0.60)$ and "encourages me and my partner to talk together about prenatal screening that pregnant women preferred" $(\bar{x}=3.53$, $S D=0.62)$ that means both of items were important to perceived by pregnant women.

The last subscale of this study was decision making. Almost of midwives thought that "asks pregnant women to explain her decision to take/not to take the prenatal tests" ( $\bar{x}=3.75, S D=0.49)$ was the most important item during counselling. All of midwives agreed that "provides medical information about the anomalies that are being tested for" ( $\bar{x}=3.65$, $S D=0.48$ ), "asks whether pregnant women`s family, friends, or other people close to clients would support client's decision to terminate the pregnancy if the child were to have a congenital abnormality" and "responds to what pregnant women already know about prenatal screening" ( $\bar{x}=3.58, S D=0.50$ ), those items linked each other to provide counselling process successfully. Based on pregnant women finding about decision making, shows that "provides medical information about the anomalies that are being tested for" ( $\bar{x}=3.53, S D=0.59)$ was the highest item that pregnant women preferred about midwives performed. The most of pregnant women assessed that "tells me what the Indonesia government aims to achieve by providing prenatal tests" ( $\bar{x}=3.42, S D=0.70)$, "talks to me about how my family and I would react to a child with a birth defect" $\quad(\bar{x} \quad=3.41, \quad S D=0$ 
Table 1

Descriptive analysis of midwives performed and pregnant women preferences with a total of 55 items

\begin{tabular}{|c|c|c|c|c|c|c|c|c|c|}
\hline \multirow[t]{2}{*}{ No } & \multirow[t]{2}{*}{$\begin{array}{l}\text { Items } \\
\text { (pregnant women version) }\end{array}$} & \multicolumn{3}{|c|}{$\begin{array}{c}\text { Midwives } \\
\text { Performance }\end{array}$} & \multicolumn{5}{|c|}{$\begin{array}{l}\text { Pregnant women } \\
\text { Preferences }\end{array}$} \\
\hline & & $n$ & $M$ & $S D$ & Rank & $n$ & $M$ & $S D$ & Rank \\
\hline \multicolumn{2}{|c|}{ Client-midwives Relationship } & & 53.80 & 4.62 & & & 50.26 & 5.51 & \\
\hline PQ1 & takes plenty of time to answer my questions & 38 & 3.60 & 0.59 & 8 & 188 & 3.49 & 0.62 & 1 \\
\hline PQ2 & puts me at ease & 38 & 3.68 & 0.57 & 2 & 186 & 3.39 & 0.63 & 6 \\
\hline PQ3 & takes my concerns seriously & 39 & 3.67 & 0.52 & 3 & 189 & 3.40 & 0.61 & 5 \\
\hline PQ4 & listens to what I am trying to ask & 40 & 3.57 & 0.50 & 10 & 188 & 3.39 & 0.61 & 6 \\
\hline PQ5 & is open and honest about every aspect of my pregnancy & 40 & 3.65 & 0.48 & 4 & 188 & 3.41 & 0.62 & 3 \\
\hline PQ6 & gives me enough time to explain myself properly & 39 & 3.53 & 0.55 & 12 & 178 & 3.41 & 0.62 & 3 \\
\hline PQ7 & shows empathy & 39 & 3.65 & 0.53 & 4 & 177 & 3.36 & 0.70 & 10 \\
\hline PQ8 & knows what I am talking about & 39 & 3.43 & 0.54 & 14 & 173 & 3.20 & 0.71 & 14 \\
\hline PQ9 & makes clear that I can ask anything I want to know & 40 & 3.62 & 0.49 & 7 & 188 & 3.32 & 0.62 & 11 \\
\hline PQ10 & uses clear and comprehensible language & 40 & 3.75 & 0.43 & 1 & 188 & 3.48 & 0.62 & 2 \\
\hline PQ11 & gives me (additional) written information & 39 & 3.57 & 0.54 & 10 & 168 & 3.20 & 0.72 & 14 \\
\hline PQ12 & $\begin{array}{l}\text { tells me that I can always contact her/him with any question I may } \\
\text { have (including when the practice is closed }\end{array}$ & 39 & 3.40 & 0.63 & 15 & 171 & 3.25 & 0.73 & 12 \\
\hline PQ13 & accepts my decision on whether or not to agree to prenatal testing & 38 & 3.45 & 0.59 & 13 & 170 & 3.21 & 0.72 & 13 \\
\hline PQ14 & paints a realistic picture (not just through 'rose-tinted spectacles') & 39 & 3.63 & 0.54 & 6 & 176 & 3.37 & 0.71 & 8 \\
\hline PQ15 & gives me the feeling that she is tuning in to me as a person & 40 & 3.60 & 0.49 & 8 & 187 & 3.37 & 0.68 & 8 \\
\hline \multicolumn{2}{|c|}{ Health Education } & & 86.07 & 6.23 & & & 81.09 & 9.36 & \\
\hline PQ16 & is professional & 40 & 3.82 & 0.38 & 1 & 193 & 3.54 & 0.58 & 1 \\
\hline PQ17 & provides information on prenatal tests & 40 & 3.60 & 0.49 & 11 & 178 & 3.35 & 0.70 & 16 \\
\hline PQ18 & $\begin{array}{l}\text { encourages me and my partner to talk together about prenatal } \\
\text { screening }\end{array}$ & 39 & 3.72 & 0.50 & 5 & 188 & 3.53 & 0.62 & 2 \\
\hline PQ19 & explains which anomalies can be identified using prenatal tests & 40 & 3.53 & 0.50 & 17 & 189 & 3.48 & 0.61 & 4 \\
\hline PQ20 & explains which anomalies can NOT be identified using prenatal tests & 40 & 3.43 & 0.50 & 22 & 191 & 3.37 & 0.63 & 15 \\
\hline PQ21 & $\begin{array}{l}\text { discusses possible negative implications of prenatal screening for the } \\
\text { unborn child }\end{array}$ & 40 & 3.73 & 0.45 & 4 & 183 & 3.41 & 0.68 & 5 \\
\hline
\end{tabular}


PQ22 explains usefulness of prenatal screening (what can a client do with it after obtaining results)

PQ23 tells me about all different types of prenatal tests available

PQ24 tells me how prenatal screening can affect my emotions and mental well-being

PQ25 tells me how much prenatal tests cost

PQ26 asks about my family's history of birth defects PQ27 explains how often congenital anomalies occur in pregnant women of my age

PQ28 explains how the changes of a birth defect are calculated for our unborn child

PQ29 tells me about my chances of having a child with a congenital abnormality during the pregnancy

PQ30 talks to me about how my risk of having a child with a birth defect will affect me

PQ31 explains why the client is or is not eligible for certain prenatal tests

PQ32 explains what will happen during prenatal tests

PQ33 explains which prenatal tests will be performed first and which will be explains which prenatal tests will be performed first and which will be
performed later, if required and/or necessary

PQ34 explains who will give me the results of the prenatal tests and how (verbally, in writing or by telephone)

PQ35 explains how long I may take to decide whether or not to have the prenatal tests

PQ36 explains how long I may take to decide whether or not to terminate the pregnancy, should the test results show an abnormality

PQ37 discusses all my options with regard to prenatal screening and the implications

PQ38 only discusses specific information about follow-up tests and possible defects with me if it becomes clear that I will need them

PQ39 makes sure that the topics I consider to be important are discussed at length

\section{Decision Making}

PQ40 tells me which Internet sites I can use to find information about prenatal testing

PQ41 is understanding about my ideological background or my religion

PQ42 enquires about my standards, values, and views on prenatal tests

PQ43 asks me questions that make me think

PQ44 is interested in who I am

PQ45 responds to what I already know about prenatal screening

PQ46 provides medical information about the anomalies that are being tested for 


\section{prenatal tests}

PQ49 talks to me about how my family and I would react to a child with a birth defect

PQ50 asks me to explain my decision to take/not to take the prenatal tests

PQ51 asks whether my family, friends, or other people close to me would support my decision about prenatal screening

asks me what I think constitutes a healthy child

PQ53 asks whether test results indicating that my unborn child has a birth defect would cause problems with my conscience

PQ54 asks whether my family, friends, or other people close to me would support my decision to terminate the pregnancy if the child were to have a congenital abnormality

PQ55

\begin{tabular}{|c|c|c|c|c|c|c|}
\hline 3.38 & 0.74 & 12 & 165 & 3.31 & 0.80 & 6 \\
\hline 3.55 & 0.59 & 5 & 177 & 3.41 & 0.71 & 3 \\
\hline 3.75 & 0.49 & 1 & 174 & 3.34 & 0.72 & 4 \\
\hline 3.50 & 0.55 & 6 & 173 & 3.25 & 0.70 & 9 \\
\hline 3.50 & 0.55 & 6 & 178 & 3.31 & 0.69 & 6 \\
\hline 3.45 & 0.55 & 11 & 179 & 3.28 & 0.65 & 8 \\
\hline 3.58 & 0.50 & 3 & 176 & 3.25 & 0.75 & 9 \\
\hline 3.50 & 0.55 & 6 & 178 & 3.34 & 0.69 & 4 \\
\hline 195.47 & 15.60 & & & 183.32 & 20.27 & \\
\hline
\end{tabular}

Relationship between Pregnant Women Demographic/Obstetrics Information and Counseling Subscales (Pregnant Women-Midwives Relationship, Health Education and Decision Making)

Based on the results, shows that age, religion, gestation week and family history were not significantly related to any subscales during prenatal congenital anomaly screening counseling (pregnant women-midwives relationship, health education and decision making) ( $p>.05)$. In this study, all of the pregnant women were married; therefore there was not result available for marriage status. Respondents' education $(p<.05)$ was the only one of demographic data that statistically contributed to pregnant-midwives relationship. Based on the results, pregnant women-midwives relationship was more influenced by women who finished their junior high school, senior high school and university level than women with no education. Another findings are respondent's education $(p<.05)$ was statistically related to health education during counselling. In this finding, there were senior high school and no education influenced the health education. Pregnant women who finished senior high school were more affected to health education than pregnant women who had no education. Variety results were perceived by parity data. Another result shows that parity was related to health education process during counseling $(p<.05)$. Finding shows that less parity will more influence to health education during counselling process.

\section{Relationship between midwives' demographic information and counseling} subscales

The results showed that, there were no statistically significance results between midwives demographic data (age, education, religion, work experiences and counseling training) and counseling subscales (pregnant women-midwives relationship, health education and decision making).

\section{Comparison between Midwives Performance and Pregnant Women Preferences during Counselling Anomaly Screening}

There was statistically significant result $(p<.05)$ for three dimensions of counselling (pregnant women-midwives relationship, health education, and decision making). The variability of pregnant women-midwives relationship was mainly resulted from midwife`s individual different (within midwives variance) $(72.3 \%)$, only few caused by different midwife (between midwives variance) $(27.7 \%)$ (Table 2). As showed from table 3, health education resulted that different midwives $(69.3 \%)$ more affected health education during counselling than individual midwife factor $(30.1 \%)$. However, in Table 4 , the variability of decision making, the most caused by individual different of midwives (74.1\%), than different of midwives (25.8\%). 
Table 2

Pregnant women' preferences and midwives' performance matched about prenatal congenital anomaly screening counseling in pregnant women-midwives relationship

\begin{tabular}{|c|c|c|c|c|c|}
\hline \multirow[b]{2}{*}{ Effect } & \multirow[b]{2}{*}{ Estimate } & \multirow[b]{2}{*}{$S E$} & \multicolumn{2}{|c|}{$\begin{array}{c}95 \% \text { confidence } \\
\text { Interval }\end{array}$} & \multirow{2}{*}{$\begin{array}{l}\text { Shared } \\
\text { Varian } \\
\text { ce }(\%)\end{array}$} \\
\hline & & & $\begin{array}{l}\text { Lower } \\
\text { Bond }\end{array}$ & $\begin{array}{l}\text { Upper } \\
\text { Bond }\end{array}$ & \\
\hline \multicolumn{6}{|l|}{ Fixed effects } \\
\hline Intercept & $50.26 * *$ & 0.57 & 49.12 & 51.41 & \\
\hline \multicolumn{6}{|l|}{ Random effects } \\
\hline $\begin{array}{l}\text { Between-midwives } \\
\text { variance }\end{array}$ & $8.47^{* *}$ & 2.96 & 4.27 & 16.81 & 27.7 \\
\hline $\begin{array}{l}\text { Within midwives } \\
\text { variance }\end{array}$ & $\begin{array}{l}22.12 * \\
*\end{array}$ & 2.47 & 17.77 & 27.54 & 72.3 \\
\hline Total Variance (\%) & 30.59 & & & & \\
\hline$* * p<$ & & & & & \\
\hline
\end{tabular}

Table 3

Pregnant women' preferences and midwives' performance matched about prenatal congenital anomaly screening counseling in health education

\begin{tabular}{|c|c|c|c|c|c|}
\hline \multirow{2}{*}{ Effect } & \multirow{2}{*}{ Estimate } & \multirow{2}{*}{$S E$} & \multicolumn{2}{|c|}{$\begin{array}{l}95 \% \text { confidence } \\
\text { Interval }\end{array}$} & \multirow{2}{*}{$\begin{array}{l}\text { Shared } \\
\text { Varian } \\
\text { ce }(\%)\end{array}$} \\
\hline & & & $\begin{array}{l}\text { Lower } \\
\text { Bond } \\
\end{array}$ & $\begin{array}{l}\text { Upper } \\
\text { Bond } \\
\end{array}$ & \\
\hline $\begin{array}{l}\text { Fixed effects } \\
\text { Intercept } \\
\text { Random effects }\end{array}$ & $51.96^{* * *}$ & 0.74 & 50.47 & 53.45 & \\
\hline $\begin{array}{l}\text { Between- midwives } \\
\text { variance }\end{array}$ & $33.93 * *$ & 4.99 & 7.83 & 28.83 & 69.3 \\
\hline $\begin{array}{l}\text { Within midwives variance } \\
\text { Total Variance }(\%)\end{array}$ & $\begin{array}{l}15.02 * * \\
48.95\end{array}$ & 3.79 & 27.25 & 42.25 & 30.7 \\
\hline
\end{tabular}

Table 4

Pregnant women' preferences and midwives' performance matched about prenatal congenital anomaly screening counseling in decision making

\begin{tabular}{|c|c|c|c|c|c|}
\hline \multirow{2}{*}{ Effect } & \multirow{2}{*}{ Estimate } & \multirow{2}{*}{$S E$} & \multicolumn{2}{|c|}{$\begin{array}{l}95 \% \text { confidence } \\
\text { Interval }\end{array}$} & \multirow{2}{*}{$\begin{array}{l}\text { Shared } \\
\text { Varianc } \\
e(\%)\end{array}$} \\
\hline & & & $\begin{array}{l}\text { Lower } \\
\text { Bond }\end{array}$ & $\begin{array}{l}\text { Upper } \\
\text { Bond }\end{array}$ & \\
\hline \multicolumn{6}{|l|}{$\overline{\text { Fixed effects }}$} \\
\hline Intercept & $51.96 * *$ & 0.74 & 50.47 & $\lceil 3.45$ & \\
\hline \multicolumn{6}{|l|}{ Random effects } \\
\hline Between midwives variance & $22.77 * *$ & 8.24 & 11.19 & 16.29 & 25.8 \\
\hline Within midwives variance & $65.30 * *$ & 7.30 & 52.45 & 31.30 & 74.1 \\
\hline Total Variance $(\%)$ & 88.07 & & & & \\
\hline$* * p<.01$ & & & & & \\
\hline
\end{tabular}

\section{DISSCUSSION}

\section{Characteristic of Pregnant Women}

Population of this study was only $0.0037 \%$ of whole pregnant women in Indonesia. However, the mean age of this study was slightly different to the mean age of pregnant women in Indonesia. The mean age of pregnant women was 25.26 years old (this study) and 22.8 years old (Indonesia) (Central Intelligence Agency, 2012). As remember, this study was taken in urban area where the education level higher than rural area $(\mathrm{OECD}, 2010)$. Examining the Indonesia Demographic Health Survey (2010) showed that the results on the type of diploma achieved in Indonesia, shows that the number of female who attained a primary school (31.9\%) was the highest, senior high school and junior high school was $17.6 \%$ and $17.2 \%$ respectively (UNFPA Indonesia, 2015). However, the result in this study was lower than the other studies and did not represent the Indonesia's data. As showed that the most education level of pregnant women in this study was senior high school $(45.5 \%)$ instead of primary school $(7.5 \%)$ as mentioned in Indonesia's data above.

In this study showed that the most of religion of pregnant women were Hindu. According to the Indonesia Demographic Health Survey 2010 Census, $83.5 \%$ of Bali's population adhered to Balinese Hinduism, followed by $13.4 \%$ Muslim, Christianity at $2.5 \%$, and Buddhism $0.5 \%$. In Indonesia there is no a certain gestation week to get counseling for pregnant women during pregnancy. The screening depends on the gestation weeks. For example, an ultrasound investigation is offered at week 18-20 of gestation to identify major structural and genetic syndromes (De Jong, Dondorp, de DieSmulders, Frints, \& de Wert, 2010), a maternal blood sample could be check as early as 7 weeks of gestation (Wright \& Burton, 2008). All of those screenings will do during trimester I-II for prevention. The most of pregnant women in this study were multiparous as same as a study that required more multiparous than nulliparous 65\% and 35\% respectively (Hanprasertpong et al., 2013). Indonesia statistic did not show the population of nulliparae and multiparae data. However, there was 2.6 of total fertility rate (TFR) in Indonesia (Indonesia Demographic Health Survey (2012) this implied that the most of women are multipara. In this study found that no family history affect to counseling. the opposite findings from some studies, mentioned that positive/ significant of family history issues that warranted further counseling/testing during gestation (Hafen, Hulinsky, Simonsen, Wilder, \& Rose, 2009).

\section{Characteristic of midwives}

The average age of midwives who gave the prenatal counseling was similar to mean age of midwives in Indonesia, 31.20 years old and 31.32 years old, respectively (Husna \& Besral, 2009). In Indonesia, Diploma III is the lowest education requirement for midwives. Diploma III education was continued program from senior high school directly, for 3 years. The average age of high school graduation was 18-19 years old, therefore they could obtain DIII degree at 21-22 years old and they allowed working in hospital directly. A study stated that mean years of midwives work experience was 11.5 
years $(S D=9.3)$ as counselor on congenital anomaly (Martin et al., 2014). However, if do a comparison to Indonesia midwives' works experiences, the mean of this study (9.33 year) was lower than mean of Indonesia's midwives' works experiences (19 years) (Rumita, 2012). Usually there are connected between work experience and counseling training. In accordance with Law No. 36 of 2014, article 46 showed that every health worker who practices should be licensed and one of the requirements is the midwives required trainings certificate (Indonesia of Health Minister, 2010b). The common training that every province conducted was counselling training in Indonesia. The demographic data of midwives were not represent Indonesia condition because lack of the sample size during study.

\section{Frequencies of Midwives Performance and pregnant women preferences on congruence during Counseling Anomaly Screening Counselling}

On the pregnant women-midwives relationship level congruence between midwives was higher $(6.5 \%)$ than pregnant women. It may lead to a situation where the relationship between midwife and woman takes priority over the client's or woman's care needs. Despite the relatively positive relation between midwives-pregnant women, the offered health education was also important in counseling. In this study, the result of health education showed that midwives were higher than pregnant women preference as performance well, there was a slightly difference between midwives and pregnant women percentage. Midwives, like other antenatal counselors (Yu, 2011), may have problems addressing all health education topics and pregnant women can learn the information by midwives. Therefore, it may be that this information is seen as less important for achieving informed decision making (Martin et al., 2014) in pregnant women during counseling for congenital anomaly. In literature there is no consensus about what information should be given (Schoonen et al., 2011a), only partially account for the perspective and preferences of clients; they are based on expert group opinions (Schoonen et al., 2011a \& 2011b). The most role of midwives in Indonesia during counseling, was given advice using a directive approach of counseling to the patients an active counseling approach was also recommended by other studies (Pensieri \& Pennacchini, 2011; Vanstone, Kinsella, \& Nisker, 2012; Van Zwieten, 2008).
Descriptive Analysis of Each Items Ranked Based on QOUTE Prenatal Questionnaire (Midwives Version and Pregnant Women Version)

Pregnant women were prefer to get time for discussion, self issues explanation than midwives in this study seem to perceive to be important for performance counseling. People may choose to speak to a counselor because they feel they cannot speak to their friends or family about such personal issues, or they may simply wish to speak to a professional with an objective viewpoint. Clients bring the everyday responses and distortions of life into the relationship with the counselors, who as a professional, can recognize these problems that are interfering with clients' daily functioning (Kahn, 1991). Communication provided antenatal has been shown to be an effective strategy to improve maternal understanding and health practices (Moran et al., 2006; Syed, Asiruddin, Helal, Mannan, \& Murray, 2006). In many developing countries, information is lacking on the intrinsic quality of communication, limiting one's ability to assess intervention effects (Harting, van Assema, van der Molen, Ambergen, \& de Vries, 2004). Regarding the health education component items, shows midwives and pregnant women relatively had similar thinking that professionalism and discussed about screening choices were the most items to get performed well in prenatal counseling. Midwives and other professionals who provide antenatal counseling should discuss their attitude towards their role as antenatal counselor with clients in order to ensure that client' preferences may be met in conformity with professional standards (Martin et al., 2014). Prior to initiating, counselling midwives might be advised to consider first whether a client wants support with decision making. The items that pregnant women concerned on midwives' performance were medical information. Interestingly, the medical information also as the highest item that midwives concerned. Counseling sessions differ in the amount and quality of the information they can provide, and often counselees are left with a feeling of little control over the condition (Van Zuuren, van Schie, \& van Baaren, 1997). A study found that $44 \%$ reported that information (across content categories) expressed in probability terms was most helpful for their decision (Shiloh et al., 2006). As predicted by Huber's model of risky decision making, they appraised information about potential consequences of choices and of possible controlling actions (prevention and treatment) as most helpful (Huber, Wider, \& Huber, 1997). 


\section{Pregnant Women' Demographic / Obstetrics Information and the Preferences of Prenatal Congenital Anomaly Screening Counseling}

Education showed significance results in counselling process. The mother's education level will affect the consistency of her decisions in prenatal screening counseling. This relationship seems to be due to the increased level of information of pregnant women and their ability to make more informed choices (Van den Berg, Timmermans, ten Kate, van Vugt, \& van der Wal et al., 2005). The same result found that education level of counselee was more important in explaining the nature of the interaction for pregnant women to discuss and the participated in the decision making process. In consultations with higher educated women, less psychosocial exchange took place. Possibly, in these consultations too, more emphasis is put on the medical technical information (Aalfs, Oort, de Haes, Leschot, \& Smets, 2006).

The most of pregnant women was on the 2-4 parities in this study. The result of parity in this study was not significant to pregnant women-midwives relationship and decision making. Interestingly, there were significant results between parity and health education during counselling. Significant found because women were not specific asked how they believed their midwives determined what health information to give to them, most women spontaneously expressed believing that their midwives adapted and individualised the health education that they provided, according to their clients' parity. There were deferring opinions by both multiparous and nulliparous women on whether midwives did this assessment adequately. Many multiparous women, for instance, believed that midwives assumed they were already aware of pregnancy health recommendations from their previous pregnancies, and therefore gave them little health information. They generally judged this assessment of their health knowledge to be correct and believed it was unnecessary for the midwife to have to go through the list of "do's and don'ts" with them again (Baron et al., 2017).Women may be more likely to adhere to advice if they are told why this advice is important (Lucas, Charlton, \& Yeatman, 2014), implying that providing more detailed information beyond the basics may be efective in practice.

\section{Pregnant Women' Preferences and Midwives' Performance About Prenatal Congenital Anomaly Screening Counseling In Indonesia.}

The variability of pregnant women midwives relationship and decision making were more caused by within midwife than different midwives variance which implied that different midwives gave difference performance during pregnant womenmidwives relationship and decision making, because midwives built the relationship and decision making process based on pregnant women needs. Addressing women's choices should be recognised as being integral to the decision-making process. Communication and information should be provided in a form that is accessible to pregnant women who have additional needs, such as those with physical, cognitive or sensory disabilities and those who do not speak or read English (National Collaborating Centre for Women's and Children's Health (UK), 2008). This findings were supporting by some studies. Similarly, Edwards (2000) found that women defined their need for support from a holistic viewpoint - they wanted both physical and emotional support from the midwife. At times, the midwives felt that they were able to make a significant difference to the women in their care, and when this happened they appeared to feel very positive (Thomas, 2009). Stevens (2003) findings support this for midwives in caseload practice, who appeared to gain substantial satisfaction from the close relationship with women, and as a result were more willing to make themselves available and responsive to women's needs.

However, health education resulted that more caused by different midwives variance than within midwife variance. This is means different midwives gave different performance on the same contents of health education during prenatal anomaly counselling. Genetic counseling activities need to be offered by a wider group of health professionals, so as to provide genetic information and education (Frazier, Tix, \& Barron, 2004). Baron et al. (2017) found the opposite finding related to health education perceived by pregnant women. Their findings were women believed that midwives individualised health education by estimating their clients' knowledge, according to characteristics, such as their parity. Women also believed that much health education provided by the midwives was driven by their own questions (Baron et al., 2017). As remember that in this study only focus on age, education, religion, counselling training of midwives and they were no any significant results to midwives' performance. Additionally, in this study 
there was no specific skill training or any protocol explained that the different midwives gave different performance in health education, and also the researcher was collected 40 midwives which were very small number of sample size. Therefore, no enough factors that could support the reasons of different midwives gave different performance in health education as finding in this study.

\section{CONCLUSION}

The conclusion of this study are midwives give counseling on pregnant women relationship and decision making based on pregnant women needs. For health education in prenatal congenital anomaly screenings, the midwives as counselor should build a protocol or any guidelines to ensure the counseling process based on professionalism as same as pregnant women and midwives thought that professional was the most important point to have performance well during prenatal congenital anomaly screenings counseling..

\section{ACKNOWLEDGEMENT}

Thankfully to Linda Martin who permitted me to use the instrument in this study, the participants who participated in this study from Klungkung hospitals, Sanjiwani Hospitals, Denpasar Selatan II health center and Kuta I health center and research assistant in this research study.

\section{REFERENCES}

Aalfs, C. M., Oort, F. J., de Haes, H. C. J. M., Leschot, N. J., \& Smets, E. M. A. (2006). Counselor-counselee interaction in reproductive genetic counseling: Does a pregnancy in the counselee make a difference? Patient Education and Counseling, $\quad 60(1), \quad 80-90$. doi:10.1016/j.pec.2005.03.007

Aryanto. (2008). Gangguan pemahaman bahasa pada anak down syndrome. Jakarta: EGC.

Baron, R., Heesterbeek, Q., Mannien, J., Hutton, E. K., Brug, J., \& Westerman, M. J. (2017). Exploring health education with midwives, as perceived by pregnant women in primary care: A qualitative study in the Netherlands. Midwifery, $\quad 46(1), \quad 37-44$. doi:10.1016/j.midw.2017.01.012

Basama, F. M. S., Leonard, B., \& Leighton, M. (2004). Audit: Women's perception and knowledge of the 20 weeks' anomaly scan. Journal of Obstetrics \& Gynecology, 24, 4446. doi:10.1080/01443610310001620288

Central Intelligence Agency. (2012). The world factbook: Mother's mean age at first birth. Retrieved from https://www.cia.gov/library/publications/theworld-factbook/fields/2256.html

De Jong, A., Dondorp, W. J., de Die-Smulders, C. E. M., Frints, S. G. M., \& de Wert, G. M. W. R. (2010). Non-invasive prenatal testing: Ethical issues explored. European Journal of Human Genetics, 18(3), 272-277. http://doi.org/10.1038/ejhg.2009.203

Edwards N. P. (2000). Women planning homebirths: Their own views on their relationships with midwives. The midwifemother relationship. In M. Kirkham (Ed. pp. 55-91). New York: Palgrave MacMillan.

Frazier, P. A., Tix, A. P., \& Barron, K. E. (2004). Testing Moderator and Mediator Effects in Counseling Psychology Research. Journal of Counseling Psychology, 51(1), 115-134. doi:10.1037/0022-0167.51.1.115

Hafen, L. B., Hulinsky, R. S., Simonsen, S. E., Wilder, S., \& Rose, N. C. (2009). The utility of genetic counseling prior to offering first trimester screening options. Journal of Genetic Counseling, 18(4), 395-400. doi:10.1007/s10897-009-9230-3

Hanprasertpong, T., Rattanaprueksachart, R., Janwadee, S., Geater, A., Kor-Anantakul, O., Suwanrath, C., \& Hanprasertpong, J. (2013). Comparison of the effectiveness of different counseling methods before second trimester genetic amniocentesis in Thailand. Prenatal Diagnosis, 33(12), 1189-1193. doi:10.1002/pd.4222

Harting, J., van Assema, P., van der Molen, H. T., Ambergen, T., \& de Vries, N. K. (2004). Quality assessment of health counseling: Performance of health advisors in cardiovascular prevention. Patient Education and Counseling, 54(1), 107-118. doi:10.1016/s0738-3991(03)00194-0

Huber, O., Wider, R., \& Huber, O. W. (1997). Active information search and complete information presentation in naturalistic risky decision tasks. Acta Psychologica, 95(1), 1529. doi:10.1016/s0001-6918(96)00028-5 
Husna, A., \& Besral, B. (2009). Kinerja bidan di desa dalam program jaminan pemeliharaan kesehatan masyarakat miskin. Kesehatan masyarakat: National Public Health Journal, 4(1), 18-20. doi:10.21109/kesmas.v4i1.196

Indonesia Demographic Health Survey. (2010). Sensus penduduk 2010: Penduduk menurut wilayah dan agama yang dianut [Population census 2010: Population by region and religion]. Retrieved from https://pkub.kemenag.go.id/artikel/17961/pen duduk-menurut-wilayah-dan-agama-yangdianut

Indonesia Demographic Health Survey. (2012). Statistic Indonesia 2012. Retrieved from http://dhsprogram.com/PUBS/PDF/fr275/fr27 $\underline{\text { 5.pdf }}$

Indonesia of Health Minister. (2010b). Tentang izin dan penyelenggaraan praktik bidan [about permissions and implementation of midwife practice]. Retrieved from http://www.hukor.depkes.go.id/up prod per menkes/PMK\%20No.\%201464\%20thn\%20tt $\mathrm{g} \% 20$ Izin\%20dan\%20Penyelenggaraan\%20Pr aktik\%20Bidan.pdf

Kahn, M. (1991). Between therapist and client: The new relationship. Choice Reviews Online, 29(01), 29-0601-29-0601. doi:10.5860/choice.29-0601

Korenromp, M. (2006). Prenatal adaptation to termination of pregnancy for fetal anomalies. Unpublished doctoral dissertation, University Medical Center Utrecht, Utrecht. Retrieved from:

http://nebula.wsimg.com/fa1d4fd68c64c2073 7e0a08a50543aa4?AccessKeyId=BE16207C1 CC3A18A9A3A\&disposition=0\&alloworigin $=1$

Lucas, C., Charlton, K. E., \& Yeatman, H. (2014). Nutrition advice during pregnancy: Do women receive it and can health professionals provide it? Maternal and Child Health Journal, 18(10), 2465-2478. doi:10.1007/s10995-014-1485-0

Martin, L., Hutton, E. K., Spelten, E. R., Gitsels-van der Wal, J. T., \& van Dulmen, S. (2014). Midwives' views on appropriate antenatal counselling for congenital anomaly tests: Do they match clients' preferences? Midwifery, $30(6)$,

600-609. doi:10.1016/j.midw.2013.08.012

Martin, L., Van Dulmen, S., Spelten, E., De Jonge, A., De Cock, P., \& Hutton, E. (2013). Prenatal counseling for congenital anomaly tests: Parental preferences and perceptions of midwife performance. Prenatal Diagnosis, 33(4), 341-353. doi:10.1002/pd.4074

Moran, A., Sangli,G., Dineen, R., Rawlins, B., Yameogo, M., \& Baya, B. (2006). Birthpreparedness for maternal health: Findings from Koupela district, Burkina Faso. Journal of Health Population Nutrition, 24(4), 489497.

National Collaborating Centre for Women's and Children's Health (UK). (2008). Antenatal care: Routine care for the healthy pregnant woman, NICE Clinical Guidelines. London: RCOG Press.

OECD. (2010). Pisa 2009 results: Overcoming social background: Equity in learning opportunities and outcomes II. Pisa: OECD publishing.

Pensieri, C., \& Pennacchini, M. (2011). Communication within genetic counselling. Medicina e Morale, 60(3). doi:10.4081/mem.2011.168

Rumita, E.S. (2012) Analisis Kelayakan Rujukan Persalinan Oleh Bidan Puskesmas PONED Di RSUD Pirngadi Medan [Feasibility analysis of birth reference by midwife Puskesmas PONED at Pirngadi Hospital Medan]. Unpublished master's thesis, Jambi University, Indonesia. Retrieved from: https://online-

journal.unja.ac.id/index.php/kedokteran/articl e/view/2706/1968+\&cd=2\&hl=en\&ct=clnk\& $\mathrm{gl}=\mathrm{tw} \& \mathrm{client}=$ firefox $-\mathrm{b}-\mathrm{ab}$

Schoonen, H. M. H. J. D., Essink-Bot, M. L., Van Agt, H. M. E., Wildschut, H. I., Steegers, E. A. P., \& De Koning, H. J. (2011a). Informed decision-making about the fetal anomaly scan: What knowledge is relevant? Ultrasound in Obstetrics \& Gynecology, 37(6), 649-657. doi:10.1002/uog.8906

Schoonen, H. M., van Agt, H. M. E., Essink, B. M. L., Wildschut, H. I., Steegers, E. A. P., \& de Koning, H. J. (2011b). Informed decisionmaking in prenatal screening for Down's syndrome: What knowledge is relevant? 
Patient Education \& Counseling, 84, 265270. doi:10.1016/j.pec.2010.07.037

Shaffer, L. G., Rosenfeld, J. A., Dabell, M. P., Coppinger, J., Bandholz, A. M., Ellison, J. W., \& Fisher, A. J. (2012). Detection rates of clinically significant genomic alterations by microarray analysis for specific anomalies detected by ultrasound. Prenatal Diagnosis, 32(10), 986-995. doi:10.1002/pd.3943

Shiloh, S., Gerad, L., \& Goldman, B. (2006). Patients' information needs and decisionmaking processes: What can be learned from genetic counselees? Health Psychology, 25(2), 211-219. doi:10.1037/02786133.25.2.211

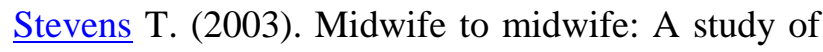
caseload midwifery. Unpublished Dissertation, Thames Valley University, London.

Sousa, V. D., \& Rojjanasrirat, W. (2010). Translation, adaptation and validation of instruments or scales for use in cross-cultural health care research: A clear and user-friendly guideline. Journal of Evaluation in Clinical Practice, 17(2), 268-274. doi:10.1111/j.13652753.2010.01434.x

Syed, U., Asiruddin, S., Helal, S., Mannan, I., \& Murray, J. (2006). Immediate and early postnatal care for mothers and newborns in rural Bangladesh. Journal of Health Population Nutrition, 24(4), 508-518. Retrieved from: https://www.ncbi.nlm.nih.gov/pmc/articles/P MC3001155/pdf/jhpn0024-0508.pdf

Thomas, B. G. (2009). Making a difference: Midwives' experiences of caring for women. Retrieved from:

https://www.rcm.org.uk/learning-andcareer/learning-and-research/ebmarticles/\%E2\% $80 \% 98$ making-adifference\%E2\%80\%99midwives\%E2\%80\%99-experiences

UNFPA Indonesia. (2015). Women and girls in
Indonesia: Progress and challenges. Retrieved from: http://indonesia.unfpa.org/application/assets/p ublications/BUKU_Monograph_No5_Women _Girls_08_Low-res.pdf

Van den Berg, M., Timmermans, D. R. M., ten Kate, L. P., van Vugt, J. M. G., \& van der Wal, G. (2005). Are pregnant women making informed choices about prenatal screening? Genetic Medication, 7(5), 332-338. doi:10.1097/01.gim.0000162876.65555.ab

Van Zuuren, F. J., Van Schie, E. C. M., \& Van Baaren, N. K. (1997). Uncertainty in the information provided during genetic counseling. Patient Education \& Counseling, 32(1-2), 129-139. doi:10.1016/s07383991(97)00052-9

Van Zwieten, M.C.B. (2008). The importance of a conscious choice but what is the choice about? The set of possibilities during decision-making about prenatal congenital anomaly tests. De Psycholoog, 43, 20-25. (in Dutch). Retrieved from http://myravanzwieten.nl/pdf/pub_artikelen_h oofdstukken/Het belang van een weloverw ogen keuze.pdf

Vanstone, M., Kinsella, E. A., \& Nisker, J. (2012). Information-sharing to promote informed choice in prenatal screening in the spirit of the SOGC clinical practice guideline: A proposal for an alternative model. Journal of Obstetrics and Gynaecology Canada, 34(3), 269-275. doi:10.1016/s1701-2163(16)35188$\mathrm{x}$

Wright, C. F., \& Burton, H. (2008). The use of cellfree fetal nucleic acids in maternal blood for non-invasive prenatal diagnosis. Human Reproduction Update, 15(1), 139-151. doi:10.1093/humupd/dmn047

Yu, J. (2011). A systematic review of issues around antenatal screening and prenatal diagnostic testing for genetic disorders: Women of Asian origin in western countries. Health \& Social Care in the Community, 20(4), 329-346. doi:10.1111/j.1365-2524.2011.01036.x 